\title{
A new view to the spatial distribution of the Paleogene lithostratigraphic units in the Goren Chiflik Horst based on borehole data
}

\author{
Boris Valchev, Hristo Dimitrov \\ University of Mining and Geology "St. Ivan Rilski”, 1700 Sofia, Bulgaria; \\ E-mails: b_valchev@mgu.bg, hristo_dimitrov@mgu.bg
}

\section{Нов поглед към пространственото разпространение на палеогенските литостратиграфски единици в Горночифлишкия хорст, въз основа на сондажни данни}

\author{
Борис Вълчев, Христо Димитров \\ Минно-геоложки университет „Св. Иван Рилски“, София 1700
}

\begin{abstract}
Резюме. Настоящата статия има за цел да представи нови данни за пространственото разпространение и литоложките особености на палеогенските литостратиграфски единици в Горночифлишкия хорст, който е част от Мизийската платформа в Източна България. Въз основа на първична литоложка информация от 29 сондажа са разпознати осем официални палеогенски литостратиграфски единици: Комаревска (Танет), Белославска (Ипрес), Дикилиташка (Ипрес), Аладънска (Ипрес), Авренска (най-горен Ипрес-най-долен Приабон), Двойнишка (Лютес) свита, Долночифлишки член на Авренската свита (Бартон-Приабон) и Русларска свита (Олигоцен). Пространственото им разпространение, както и техните взаимоотношения, са визуализирани чрез построяването на 11 геоложки разреза. Представени са допълнителни данни за литологията, дебелината, границите и възрастта им.
\end{abstract}

Ключови думи: Палеоген, литостратиграфия, сондажни разрези, геоложки разрези, Горночифлишки хорст.

\begin{abstract}
The present article aims to provide new data on the spatial distribution and lithological features of the Paleogene lithostratigraphic units in the Goren Chiflik Horst, which is part of the Moesian Platform in Eastern Bulgaria. Eight formal Paleogene lithostratigraphic units were recognized on the basis of primary lithological data derived from 29 borehole sections. They are as follows: the Komarevo Fm. (Thanetian), the Beloslav Fm. (Ypresian), the Dikilitash Fm. (Ypresian), the Aladan Fm. (Ypresian), the Avren Fm. (uppermost Ypresian-lowermost Priabonian), the Dvoynitsa Fm. (Lutetian), the Dolni Chiflik Mb. of the Avren Fm. (Bartonian-Priabonian), and the Ruslar Fm. (Oligocene). Their spatial distribution and relationships are visualized by drawing up 11 geological cross-sections. Additional data on their lithology, thickness, boundaries and age are also given.
\end{abstract}

Keywords: Paleogene, lithostratigraphy, borehole logs, geological cross-sections, Goren Chiflik Horst.

\section{Introduction}

In series of articles, we published the results of the lithostratigraphic investigation of the Paleogene in Northeastern Bulgaria (Valchev et al., 2017, 2018a, b, 2019, 2020; Valchev, Dimitrov, 2018, $2019,2020)$. They were contributions to the pioneering studies of the earlier researchers on this stratigraphic succession in this part of the country (Gočev, 1926, 1929, 1933，1934; Tzankov, 1936; Cohen, 1938; Tzankov, Beregov, 1940), their "followers" from the middle of the XX century (Mandev, 1955; Belmoustakov, 1960, 1962, 1968) and the "modern" authors Aladzova-Khrischeva
(Aladjova-Khrischeva, 1984; Aladžova-Hrisčeva, 1990; Aladjova-Chrisčeva, 1991) and Juranov (in: Dzuranov, Darakchieva, 1986; Juranov, Pimpirev, 1989), who formalized the "horizons" of their predecessors according to the requirements of the Bulgarian Stratigraphic Code (Kojumdgieva et al., 1982).

The Goren Chiflik Horst, a small tectonic unit representing a segment of the North Bulgarian Dome (sensu Dabovski, Zagorchev, 2009), is a part of the Moesian Platform in Eastern Bulgaria (Fig. 1) located between the Provadiya Syncline to the west, the Avren Step and the Dolna Kamchiya Basin to the east. It was described by Atanasoff (1961) and 

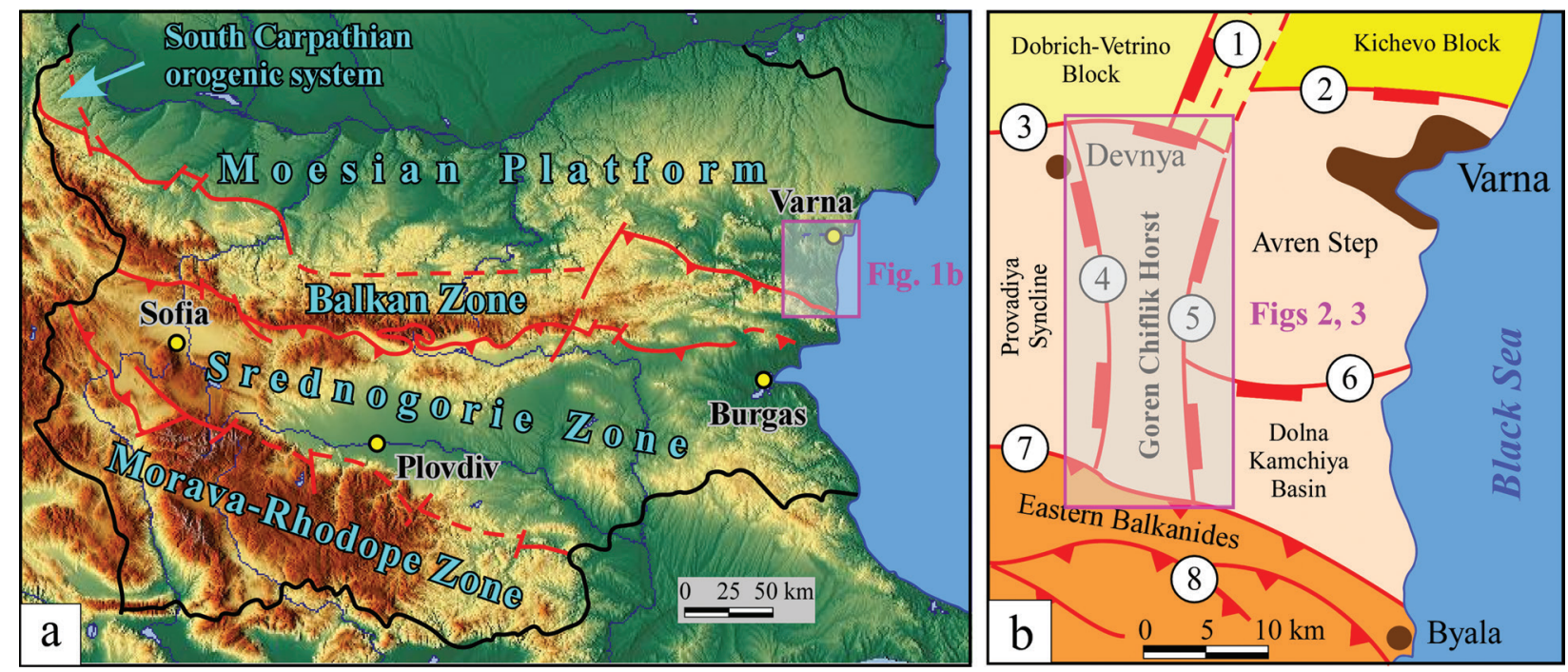

Fig. 1. a) Tectonic subdivision of the territory of Bulgaria (after Dabovski, Zagorchev, 2009) with location of the studied area; b) Tectonic subdivision of the onshore part of the Moesian Platform in Northeast Bulgaria (after Bokov et al., 1987) with location of the Goren Chiflik Horst

Faults: 1, Venelin-Dobrich zone; 2, Kichevo; 3, Resen-Medovina; 4, Kubrat-Vetrino; 5, Venelin-Aksakovo; 6, Bliznatsi; 7, Preslav-Shkorpilovtsi zone; 8 , East Balkans frontal thrust

Fig. 1. a) Тектонска подялба на територията на България (по Dabovski, Zagorchev, 2009) с разположението на изследвания район; b) Тектонска подялба на сухоземната част на Мизийската платформа в Североизточна България (по Bokov et al., 1987) с разположението на Горночифлишкия хорст

Разломи: 1 - Венелинско-Добричка зона; 2 - Кичевски; 3 - Ресенско-Медовински; 4 - Кубрат-Ветрински; 5 - ВенелинАксаковски; 6 - Близнашки; 7 - Преславско-Шкорпиловска зона; 8 - Източнобалкански челен навлак

Georgiev et al. (1988) and comprises a narrow strip (maximum width about $8 \mathrm{~km}$ at its northernmost part) along the western wedge of the Avren Plateau, the Provadijska River valley (north of the village of Yunak), and the Goren Chiflik area south of the Kamchiya River (Figs 2, 3).

The Paleogene in the study area has been investigated predominantly based on the outcrops located on the western wedge of the Avren Plateau (Belmoustakov, 1960, 1962; Aladjova-Khrischeva, 1984; Aladžova-Hrisčeva, 1990; Aladjova-Chrisčeva, 1991; Stoykova, Vangelov, 1997) and therefore, the aims of this study are: (i) to recognize the exact subsurface lithostratigraphic succession by interpretation of borehole lithological logs, (ii) to add new data concerning the lithological features and thickness, (iii) to illustrate the spatial distribution and relationships of the individual Paleogene lithostratigraphic units by drawing up geological cross-sections, and thus, (iv) to clarify the deep geologic structure of this part of the country.

\section{Studied material}

The present investigation is based on integration of the primary lithological data obtained from 29 borehole sections (the geological reports are kept at the
National Geological Fund, Ministry of Energy of the Republic of Bulgaria), which are unevenly distributed across the studied area (Fig. 3). The boreholes were drilled and studied from the middle 1960s to the late 1980s for oil and gas prospecting, and concern the following areas: Yunak (Kulev et al., 1965f $\mathrm{f}^{1}$, Baburkov, 1982f ${ }^{2}$, 1988f $\mathrm{f}^{3}$ ), Sindel-Avren (Kulev et al., 1965f), Venelin (Kulev et al., 1965f), Goren Chiflik (Monov, 1971 $\mathrm{f}^{4}$ ). Additional data on the spatial distribution of the lithostratigraphic units and the geological structure were derived on the basis of lithostratigraphic interpretation of two seismic profiles (Fig. 3).

${ }^{1}$ Kulev, N., M. Nikolova, K. Bogdanova. 1965f. Report on the Results of the Deep and Structural Drilling in the Avren Plateau in 1961-1963. Sofia, Ministry of Energy, National Geological Fund, report III-162, 246 p. (in Bulgarian, unpublished).

${ }^{2}$ Baburkov, I. 1982f. Report on the Results of the Deep Prospecting Drilling in Yunak Area conducted in 1978-1980. R-1, R-2, R-3, R-4 Yunak Boreholes. Sofia, Ministry of Energy, National Geological Fund, report III-326, 83 p. (in Bulgarian, unpublished).

${ }^{3}$ Baburkov, I. 1988f. Report on the Results of the Structural and Prospecting Drilling in Yunak Area conducted in 1977-1978. Sofia, Ministry of Energy, National Geological Fund, report III-313, 208 p. (in Bulgarian, unpublished).

${ }^{4}$ Monov, B. 1971f. Report on the Results from the Structural Drilling in Dolna Kamchiya Area conducted in 1955-1961. Sofia, Ministry of Energy, National Geological Fund, report III-235, 576 p. (in Bulgarian, unpublished). 


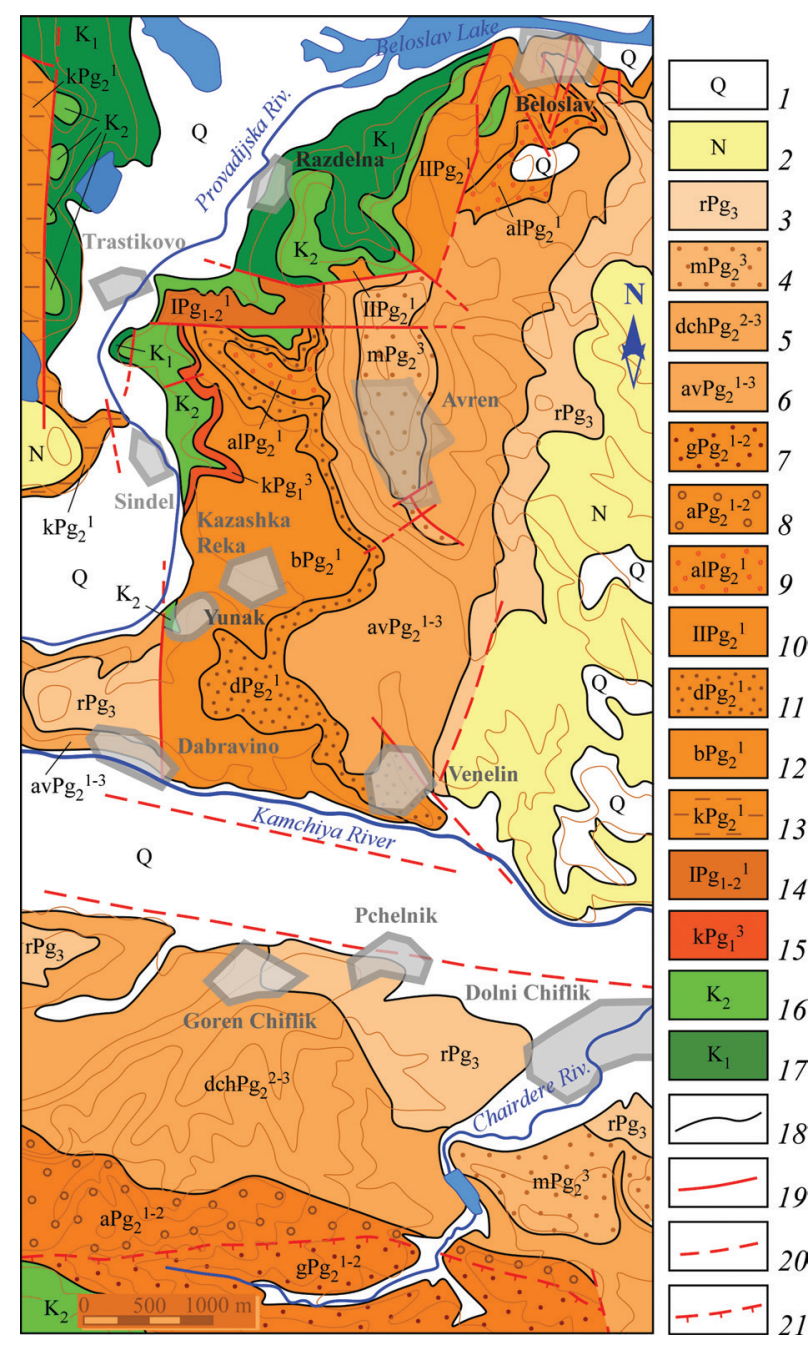

Fig. 2. Simplified geological map of the Goren Chiflik Horst and adjacent areas (after Cheshitev et al., 1991; Kânčev, Gerčeva, 1992, modified)

1, Quaternary; 2, Neogene; 3-15, Paleogene (3, Ruslar Fm., 4, Momino Fm., 5, Dolni Chiflik Mb. of the Avren Fm., 6, Avren Fm., 7, Gebesh Mb. of the Dvoynitsa Fm., 8, Armera Mb. of the Dvoynitsa Fm., 9, Aladan Fm., 10, Beloslav and Dikilitash Fms, 11, Dikilitash Fm., 12, Beloslav Fm., 13, Krivnya Fm., 14, Aladan, Dikilitash, Beloslav, and Komarevo Fms, 15, Komarevo Fm.); 16, Upper Cretaceous; 17, Lower Cretaceous; 18, lithostratigraphic boundary; 19, normal fault; 20, fossilized normal fault; 21 , fossilized trust

Фиг. 2. Опростена геоложка карта на Горночифлишкия хорст и съседните райони (по Cheshitev et al., 1991; Kânčev, Gerčeva, 1992, с изменения)

1 - Кватернер; 2 - Неоген; 3-15 - Палеоген (3 - Русларска свита, 4 - Моминска свита, 5 - Долночифлишки член на Авренската свита, 6 - Авренска свита, 7 - Гебешки член на Двойнишката свита, 8 - Армерски член на Двойнишката свита, 9- Аладънска свита, 10 - Белославска и Дикилиташка свита, 11 - Дикилиташка свита, 12 - Белославска свита, 13 - Кривненска свита, 14 - Аладънска, Дикилиташка, Белославска и Комаревска свита, 15 - Комаревска свита); 16 - Горна Креда; 17 - Долна Креда; 18 - литостратиграфска граница; 19 - разсед; 20 - фосилизиран разсед; 21 - фосилизиран навлак

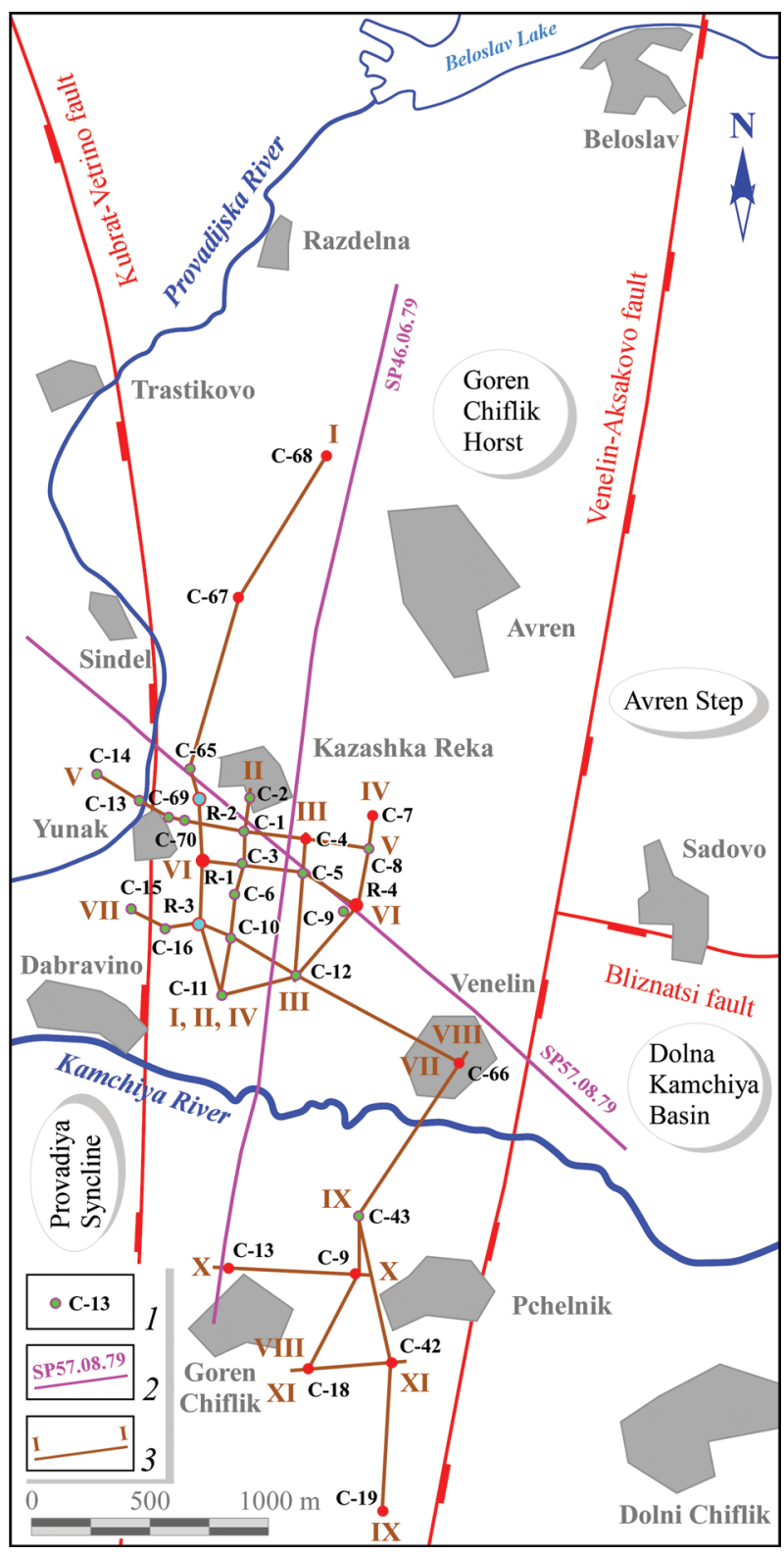

Fig. 3. Sketch map of the study area with location of the boreholes (1), seismic profiles (2), and geological cross-sections (3)

The lithological logs of boreholes, marked in red, are shown in Fig. 4

Фиг. 3. Схематична карта на изследвания район с разположението на сондажите (1), сеизмичните профили (2) и геоложките разрези (3)

Литоложките колонки на сондажите, маркирани в червено, са показани на фигура 4

\section{Lithostratigraphic units}

Based on the primary lithological data from the geological reports, we identified eight formal lithostratigraphic units in the Paleogene succession of the studied region, which are as follows: the Komarevo, Beloslav, Dikilitash, Aladan, Dvoynitsa, and Avren 
Formations, the Dolni Chiflik Member of the Avren Formation, and the Ruslar Formation. Valchev et al. (2018a, 2019, 2020) and Vangelov and Sinnyovsky (2011) discussed the nomenclature, definition, and the stratigraphic background of the units. A brief description, concerning the lithological features, thickness, age and stratigraphic relationships of each unit in the Goren Chiflik Horst, is given bellow.

\section{Komarevo Formation (Datchev, 1975)}

The unit was recorded in three boreholes located in two areas - northern, between the villages of Sindel and Avren (C-67 Sindel and C-68 Avren boreholes), and southern, around the town of Goren Chiflik (C13 Goren Chiflik). In the northern area it comprises pale-gray to white, organogenic thin-bedded limestones, containing pyrite, quartz, and glauconite grains. Rare thin layers of calcareous fine-grained sandstones also occur. The organogenic particles include small and larger foraminifera, crinoids, ostracods, and detritic lithothamnium algae. In the southern area of its distribution the unit is composed of pale-gray to dark-gray, sandy to silty and organogenic thin-bedded fractured limestones with calcite veins. Glauconite grains, rare mica flakes, feldspar grains and chert nodules also occur. Rare remains of small and larger foraminifera were recorded. The chronostratigraphic range was determined as Thanetian based on larger (Belmoustakov, 1962) and planktonic foraminifera (Juranov in: AladjovaKhrischeva et al., 1983), and calcareous nannofossils (Muzilev in: Aladzova-Khrischeva et al., 1983; Stoykova in: Stoykova, Vangelov, 1997). The thickness of the Komarevo Formation is 8-20 $\mathrm{m}$ in SindelAvren area and more than $24 \mathrm{~m}$ in the area of Goren Chiflik (here the lower boundary of the unit has not been penetrated). The unit overlies unconformably different Upper Cretaceous levels usually Mezdra Formation (Yolkichev, 1986). The upper boundary is an unconformity with the Dikilitash or Dvoynitsa Formations, or with the Quaternary cover.

\section{Beloslav Formation (Gočev, 1933)}

It was established in 22 boreholes, all of them located north of the Kamchiya River. The unit comprises gray to yellowish medium- to fine-grained quartz sands with rare thin irregular interbeds of loose sandstones sometimes with clayey matrix. The chronostratigraphic range was determined as Ypresian based on nummulitic assemblages (Aladjova-Khrischeva, 1984) and calcareous nannofossils (Stoykova in: Stoykova, Vangelov, 1997). The thickness of the Beloslav Formation varies between
4 (C-9 Kazashka Reka, C-13 Yunak, C-70 Yunak boreholes) and $18 \mathrm{~m}$ (C-6 Yunak borehole), but it is usually $8-10 \mathrm{~m}$. The lower boundary is an unconformity with different levels of the Upper Cretaceous (usually Mezdra Formation), while the upper boundary is a gradual transition to the Dikilitash Formation.

\section{Dikilitash Formation (Gočev, 1933)}

It was recorded in 24 boreholes, all of them located north of the Kamchiya River. The unit is composed of gray to pale-gray and yellowish thin-bedded sandstones built up predominantly of quartz grains and containing mica flakes, pyrite and glauconite grains. Interbeds of gray-greenish clays with quartz and glauconite grains, as well as mica flakes also occur. The chronostratigraphic range was determined as Ypresian based on nummulitids (AladjovaKhrischeva, 1984). The thickness of the Dikilitash Formation varies between 9 (C-70 Yunak borehole) and $54 \mathrm{~m}$ (C-10 Yunak borehole), but it is usually $15-30 \mathrm{~m}$. The lower boundary is a gradual transition with the Beloslav Formation. The upper boundary is a sharp lithological contact with the Aladan Formation, an unconformity with the Avren Formation or with the Quaternary cover.

\section{Aladan Formation (Gočev, 1933)}

It was established in 7 boreholes, all of them located in the area south of the villages of Yunak and Kazashka Reka and north of the Kamchiya River. The unit comprises pale-gray to white cavernous detrital limestones. Detrital particles include predominantly nummulitids. The chronostratigraphic range was determined as Ypresian based on nummulitids (Aladjova-Khrischeva, 1984). The thickness of the Aladan Formation is between $17 \mathrm{~m}$ (C-8 Kazashka Reka borehole) and 27 m (R-4 Kazashka Reka borehole). The lower boundary is a sharp lithological contact with the Dikilitash Formation or an unconformity with the Upper Cretaceous base (C-66 Venelin borehole). The upper boundary is a sharp lithological contact with the Avren Formation.

\section{Dvoynitsa Formation (Juranov, Pimpirev,} 1989)

The unit was recorded in five boreholes south of the Kamchiya River. We recognized two members the Armera Member and the Gebesh Member. The first one was recorded in four boreholes. It comprises gray fine-grained, clayey to limy, middle- to thick-bedded, cavernous sandstones, predominantly 
composed of quartz. Feldspar, as well as rare glauconite grains, occur. The thickness of the Armera Member is 42-60 m. The Gebesh Member was established in two boreholes and is composed of marls and limestones. The marls are pale- to darkgray to greenish, thin-bedded, and contain numerous glauconite and pyrite grains. The limestones are gray-greenish, micrite, massive, and contain numerous glauconite grains. In some cases they pass into limy marls. The thickness of the Gebesh Member is $35-40 \mathrm{~m}$. The two members were observed together only in a single section (C-18 Goren Chiflik borehole) where the boundary between them is a sharp lithological contact. The chronostratigraphic range of the Dvoynitsa Formation was determined as Lutetian based on planktonic foraminifera (Juranov, unpublished data). The total thickness of the unit is between $42 \mathrm{~m}$ (C-13 Goren Chiflik borehole) and more than $60 \mathrm{~m}$ (C-9 Pchelnik and C-18 Goren Chiflik boreholes; the lower boundary in the last was not penetrated). The lower boundary is an unconformity with the Komarevo Formation or with the Upper Cretaceous rocks. The upper boundary is a sharp lithological contact with the Dolni Chiflik Member of the Avren Formation or an unconformity with the Ruslar Formation.

\section{Avren Formation (Gočev, 1933)}

It was established in 15 boreholes. Eleven of them, located north of the Kamchiya River, reveal the typical Avren Formation, while in the other four, drilled south of the river, the Dolni Chiflik Member was recorded. The typical Avren Formation is composed of gray to gray-greenish massive marls. They are sandy in some levels and contain mica flakes, pyrite and glauconite grains, and remains of macroflora. The chronostratigraphic range of the Avren Formation was determined as uppermost Ypresianlowermost Priabonian (based on planktonic foraminiferal data of Shutskaya et al, 1972f $\mathrm{f}^{5}$, reinterpreted by Aladjova-Chrisčeva, 1991). The thickness of the unit varies between 17 m (C-4 Kazashka Reka borehole) and $62 \mathrm{~m}$ (C-8 Kazashka Reka borehole). The lower boundary is a sharp lithological contact with the Aladan Formation or an unconformity with the Dikilitash Formation. The upper boundary is an unconformity with the Quaternary cover.

\footnotetext{
Shutskaya, E., Y. Vaptsarova, M. Tanev, B. Goncharenko, D. Dencheva, A. Dianov, K. Jekova, V. Ignatova, M. Kehayova, G. Kulaksazov, T. Nikolov, A. Olferyev, A. Pozemova, I. Sapunov, Ch. Spasov, S. Stefanov, Y. Tenchov, E. Trifonova, D. Tronkov, P. Tsaneva, V. Tsankov, S. Yanev. 1972f. Report on Topic I. Subdivision and Correlation of Borehole Sections in North Bulgaria. Sofia, Ministry of Energy, National Geological Fund, report III-247, 959 p. (in Russian).
}

\section{Dolni Chiflik Member of the Avren Formation (Pollak, 1933)}

The background of the unit was discussed by Valchev et al. (2020). It comprises an irregular alternation of marls, sandstones and siltstones with gradual transitions between them. The marls are gray to gray-greenish, sandy, and contain mica flakes and small, irregularly distributed lenses of sandstones. Detrital remains from bivalves and macroflora, as well as pyrite grains occur. The sandstones are gray, clayey-limy, fine-grained, thin-bedded. Single lenses of conglomerate, composed of limestone, sandstone and chert clasts, were also recorded. The siltstones are gray, clayey-limy, and contain small lenses of fine-grained sandstones. At the base of the unit, a $2 \mathrm{~m}$ thick layer of gray micrite dolomite was established. The chronostratigraphic range of the Dolni Chiflik Member of the Avren Formation was determined as Bartonian-Priabonian based on planktonic foraminifera (Juranov, unpublished data). The thickness of the unit varies between 319 $\mathrm{m}$ (C-13 Goren Chiflik borehole) and $558 \mathrm{~m}$ (C-18 Goren Chiflik borehole). The lower boundary is an unconformity with the Dvoynitsa Formation. The upper boundary is an unconformity with the Quaternary cover.

\section{Ruslar Formation (Zlatarski, 1927)}

The unit was recorded in two boreholes in the area of Pchelnik village, south of the Kamchiya River. It is composed of gray to yellow and brown, silty to sandy, thin-bedded clays. Small lenses or thin interbeds of fine-grained sandstones, mica flakes, quartz and pyrite grains also occur. The sandy interbeds are located predominantly in the lower levels. Rare interbeds of limy clays were recorded in the same levels. The chronostratigraphic range was determined as Oligocene based on reinterpretation of planktonic foraminiferal data of Monov (1971f). The thickness of the Ruslar Formation is between $104 \mathrm{~m}$ (C-9 borehole) and $170 \mathrm{~m}$ (C-43 borehole). The lower boundary is an uncomformity with the Dvoynitsa Formation or the Upper Cretaceous base. The upper boundary is an unconformity with the Quaternary cover.

\section{Regional lithostratigraphic aspects}

Examples of the distinguished lithostratigraphic successions in different localities are shown in Fig. 4 by illustration of 12 representative borehole sections. The spatial distribution and relationships of the lithostratigraphic units are visualized by drawing up 11 geological cross-sections (Figs 5-8), while 

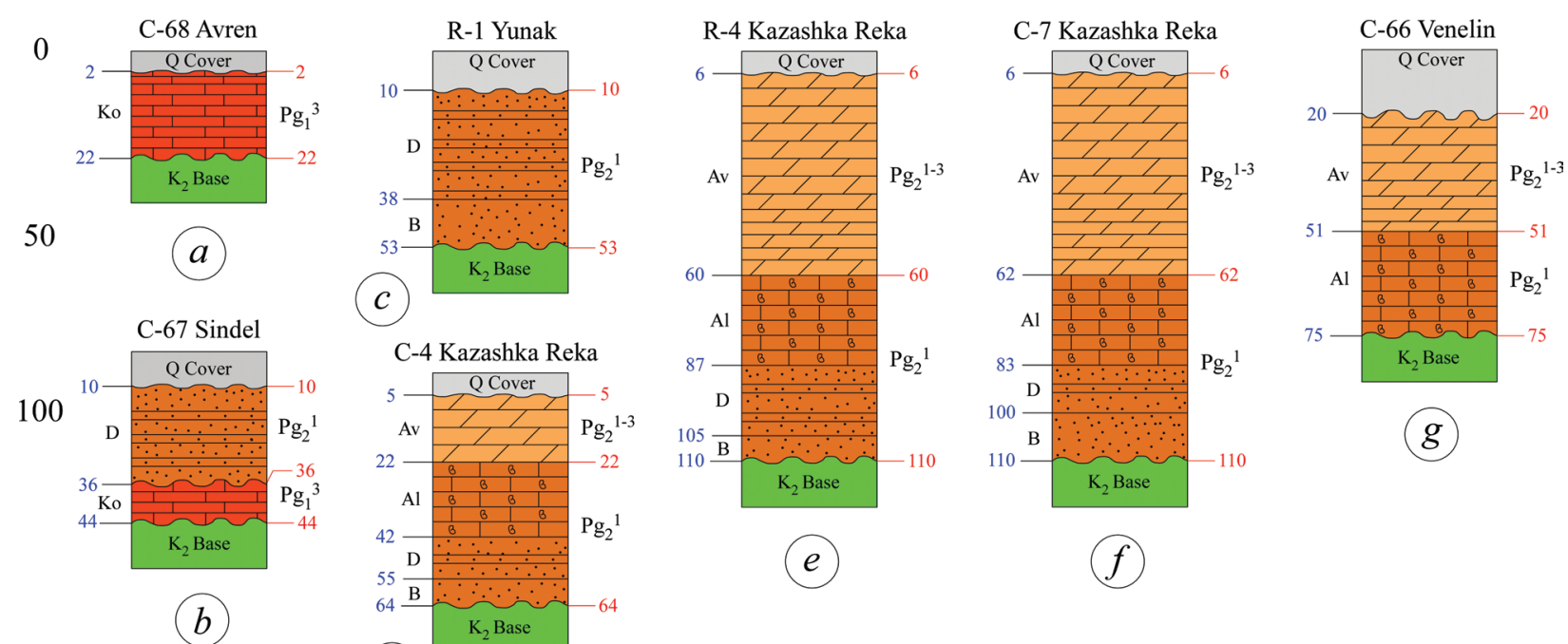

(g)
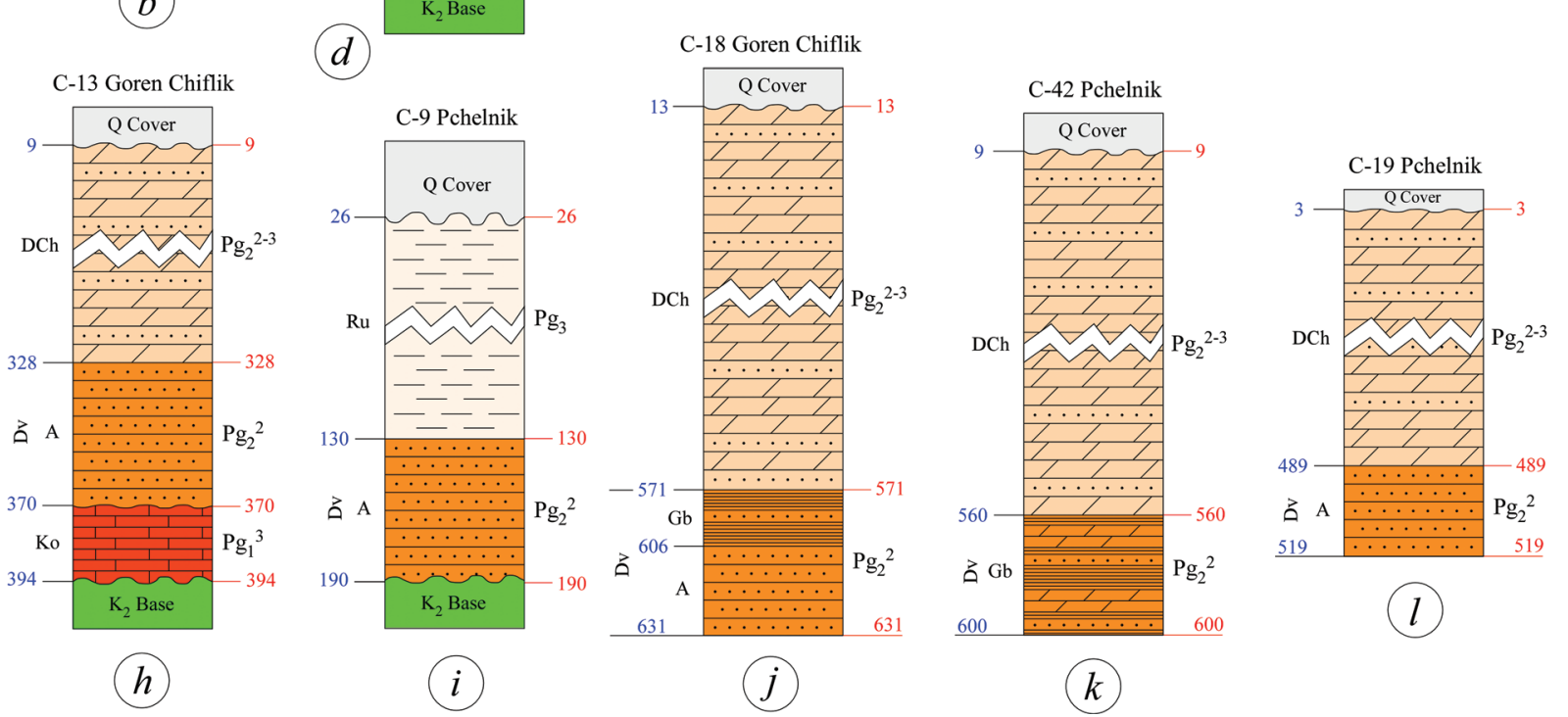

(h)

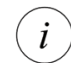

Fig. 4. Lithological logs of selected borehole sections from the studied area as examples for the recorded lithostratigraphic successions

$a-b$, Sindel-Avren area; $c-f$, Yunak area; $g$, Venelin area; $h-l$, Goren Chiflik area

Abbreviations: Ko, Komarevo Fm.; B, Beloslav Fm.; D, Dikilitash Fm.; Al, Aladan Fm.; Dv, Dvoynitsa Fm.; A, Armera Mb. of the Dvoynitsa Fm.; Gb, Gebesh Mb. of the Dvoynitsa Fm.; Av, Avren Fm.; DCh, Dolni Chiflik Mb. of the Avren Fm.; Ru, Ruslar Fm.

Фиг. 4. Литоложки колонки на избрани сондажни разрези от изучения район като примери за документираните литостратиграфски последователности

$a-b$ - площ Синдел-Аврен; $c-f$ - площ Юнак; $g$ - площ Венелин; $h-l-$ площ Горен чифлик

Съкращения: Ко - Комаревска свита; В - Белославска свита; D - Дикилиташка свита; Al - Аладънска свита; Dv - Двойнишка свита; A - Армерски член на Двойнишката свита; $\mathrm{Gb}$ - Гебешки член на Двойнишката свита; Av - Aвренска свита; $\mathrm{DCh}$ - Долночифлишки член на Авренската свита; Ru - Русларска свита

the deep geological structure is shown by lithostratigraphic interpretation of two seismic profiles (Fig. 9).

Generally, two lithostratigraphic successions were established. North of the Kamchiya River, the Paleogene comprises the Komarevo, Beloslav, Dikilitash, Aladan, and Avren Formations (Figs 4a-h, 5-7). The northernmost sections (Figs 4a, b, 5) include one (the Komarevo Fm.) or two units (the Komarevo and Dikilitash Fms), as the total thickness of the Paleogene is $20-34 \mathrm{~m}$. The most complete sections, including four units (the Beloslav,
Dikilitash, Aladan, and Avren Fms) are located in Yunak-Kazashka Reka area (Figs 4c-f, 6, 7). Here the total thickness of the Paleogene succession is 60-110 m. In the area south of Yunak and Kazashka Reka villages the Paleogene record comprises two units - the Beloslav and Dikilitash Fms (Figs 4c, 7) with total thickness $38-61 \mathrm{~m}$. In the south-easternmost area north of the Kamchiya River (the village of Venelin - Figs 4g, 7) the Aladan and Avren Fms were established. Here the total thickness of the Paleogene is $54 \mathrm{~m}$. 


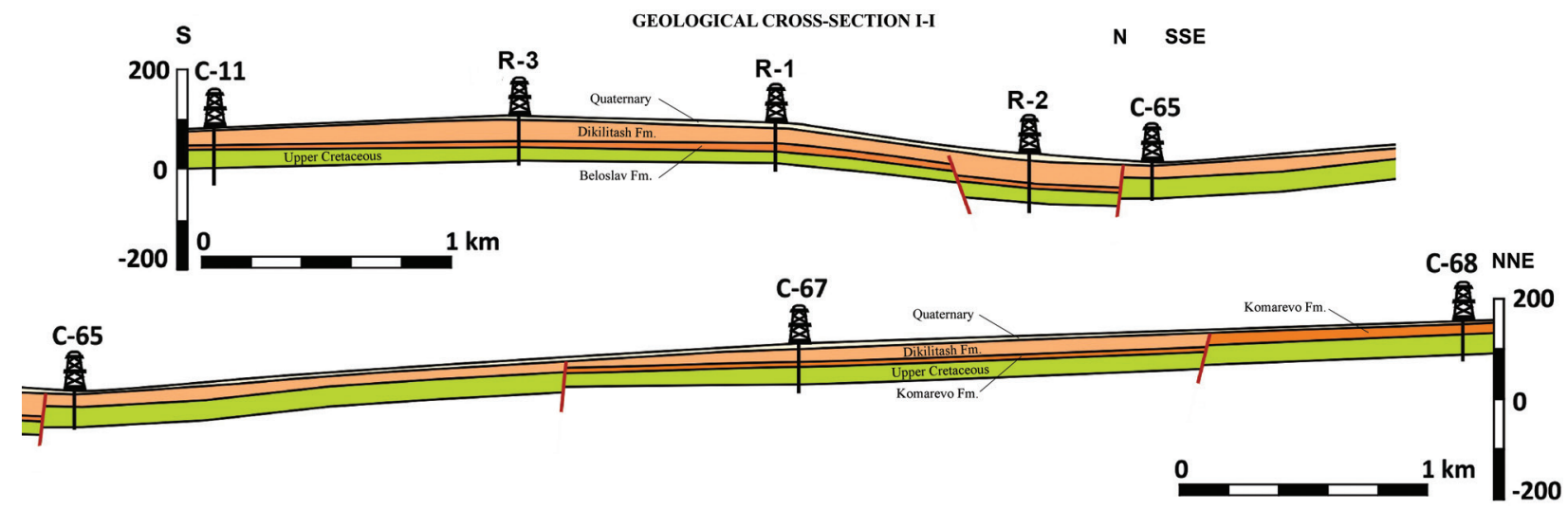

Fig. 5. Geological cross-section I-I

Фиг. 5. Геоложки разрез по линия I-I

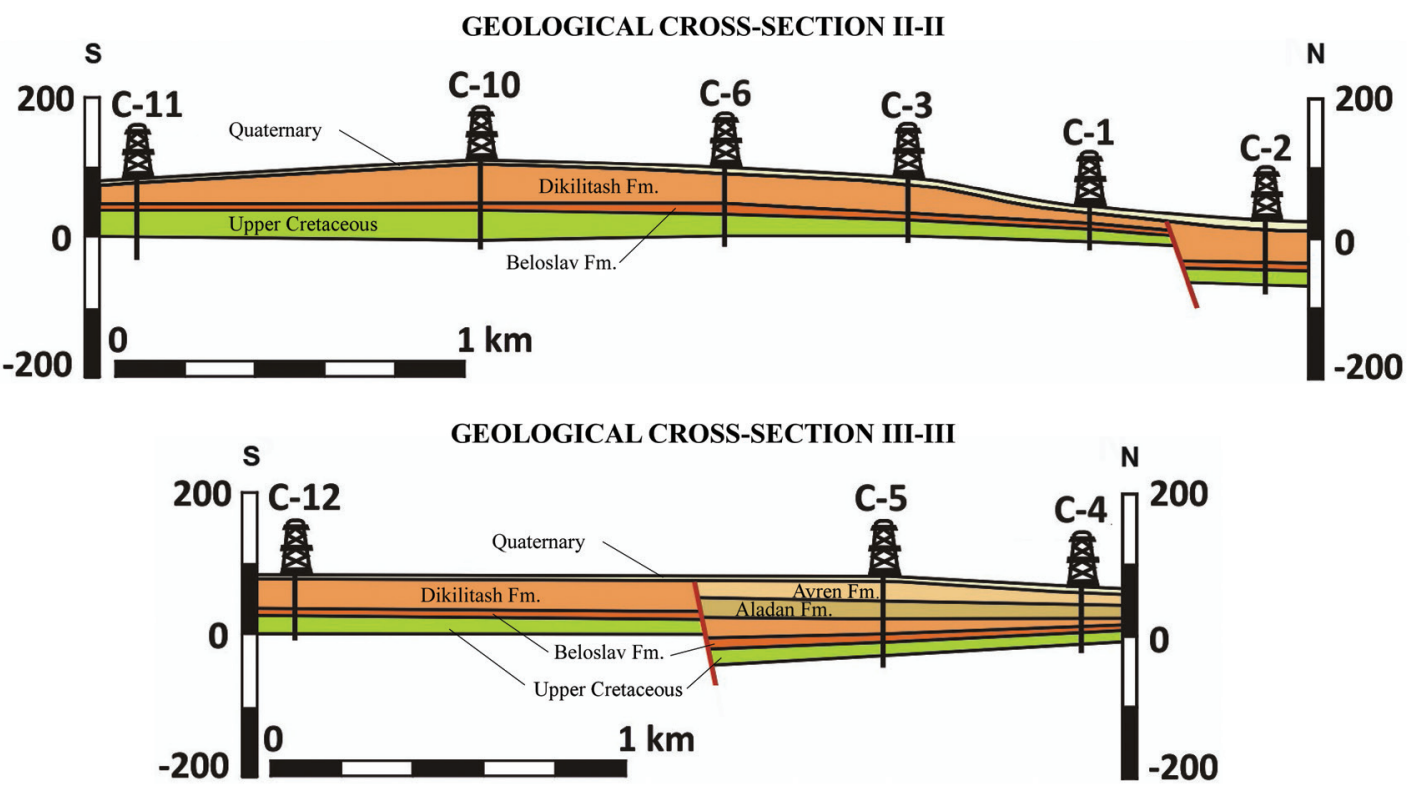

GEOLOGICAL CROSS-SECTION IV-IV

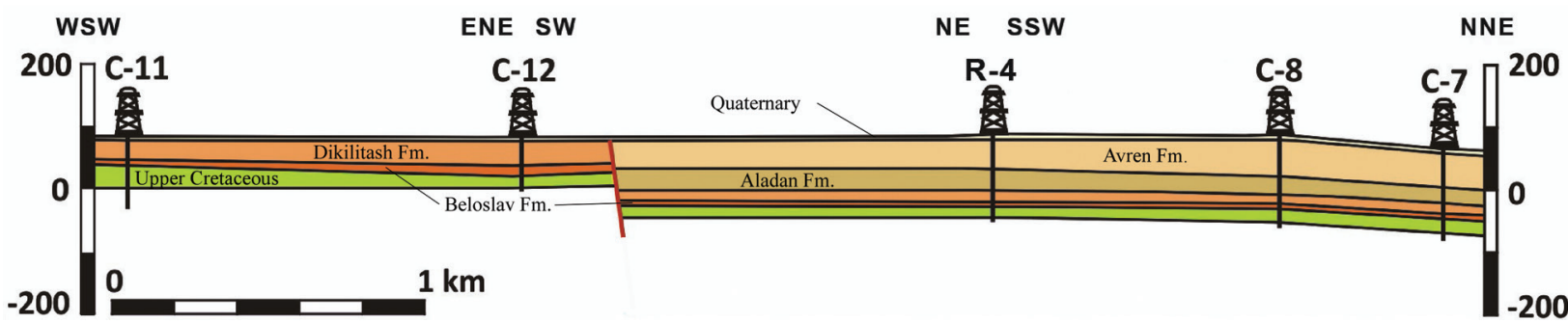

Fig. 6. Geological cross-sections II-II, and III-III, and IV-IV

Фиг. 6. Геоложки разрези по линиите II-II, III-III и IV-IV

The lithobody tentatively referred herein to the Komarevo Formation shows lithological characteristics differing from those in the type area in central North Bulgaria (Datchev, 1975). It was recorded in the northernmost part of the Goren Chiflik Horst
(Fig. 4a, b) and its thickness corresponds to that established in the outcrops along the western edge of the Avren Plateau. Compared to the adjacent areas (the Avren Step - Valchev, Dimitrov, 2020, and the Dolna Kamchiya Basin - Valchev et al., 2020) 

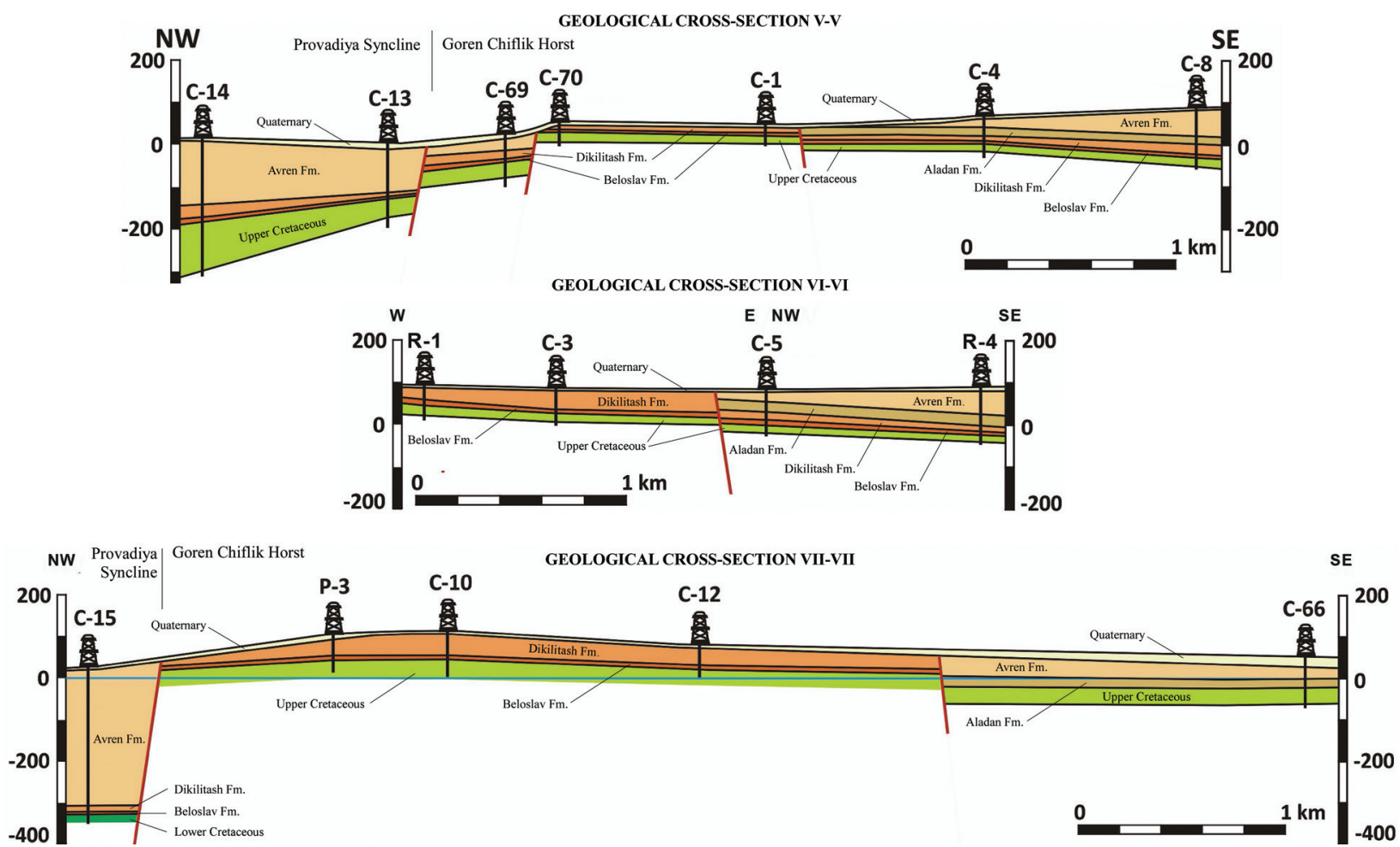

Fig. 7. Geological cross-sections V-V, VI-VI, and VII-VII

Фиг. 7. Геоложки разрези по линиите V-V, VI-VI и VII-VII

the unit in the studied area is thinner, but it demonstrates similar lithological features.

The Beloslav and Dikilitash Formations show constant color and lithology throughout the area of their distribution, which is typical for the Avren Plateau (their type area is around the town of Beloslav) and is the same as in the Dobrogea area (Valchev et al., 2018) and the Varna Plateau (Valchev et al., 2019), but the color is different from this, established in the Avren Step (Valchev, Dimitrov, 2020) and the Dolna Kamchiya Basin (Valchev et al., 2020). The thickness of the Beloslav Formation is almost constant and compared to the Avren Step, and especially to Dobrogea area and the Varna Plateau, is smaller. The Dikilitash Formation shows some thickness variations, but generally, the unit is thinner compared to Dobrogea area, the Varna Plateau, and the Avren Step. In the adjacent Dolna Kamchiya Basin these units were examined as a unified lithobody due to the indistinct boundary between them (Valchev et al., 2020), and therefore it is difficult to make a reliable comparison.

The Aladan Formation demonstrates constant lithological record and thickness throughout the entire studied area. Generally, the unit is thinner, compared to the data obtained from the Avren Step and the Dolna Kamchiya Basin.
The Avren Formation's lithology is comparatively homogenous (almost entirely marl succession), and its thickness is constant. Thus, the unit's characteristic features differ considerably from these in the other studied areas in Northeastern Bulgaria.

In the southern part of the Goren Chiflik Horst (south of the Kamchiya River), the Paleogene is represented by the Komarevo and Dvoynitsa Formations, the Dolni Chiflik Member of the Avren Formation, and the Ruslar Formation (Figs $4 \mathrm{~h}-1,8$ ). In the area northwest to the village of Goren Chiflik (Figs 4h, 8) the Paleogene succession includes three units (the Komarevo Fm., the Armera Mb. of the Dvoynitsa Fm., and the Dolni Chiflik Mb. of the Avren Fm.) with total thickness $385 \mathrm{~m}$. The sections located south of the villages of Goren Chiflik and Pchelnik (Figs. 4j-1, 8) are composed of the Dvoynitsa Fm. (the Gebesh or/and Armera Mbs) and the Dolni Chiflik Mb. of the Avren Fm., as their total thickness is $516-618 \mathrm{~m}$. North-western to the village of Pchelnik (Fig. 4i, 8) the Paleogene is represented by the Dvoynitsa (the Armera $\mathrm{Mb}$.) and Ruslar Fms or by the last only. The total thickness is $164-170 \mathrm{~m}$.

The Dvoynitsa Formation shows lower lithological diversity and smaller thickness compared to the 

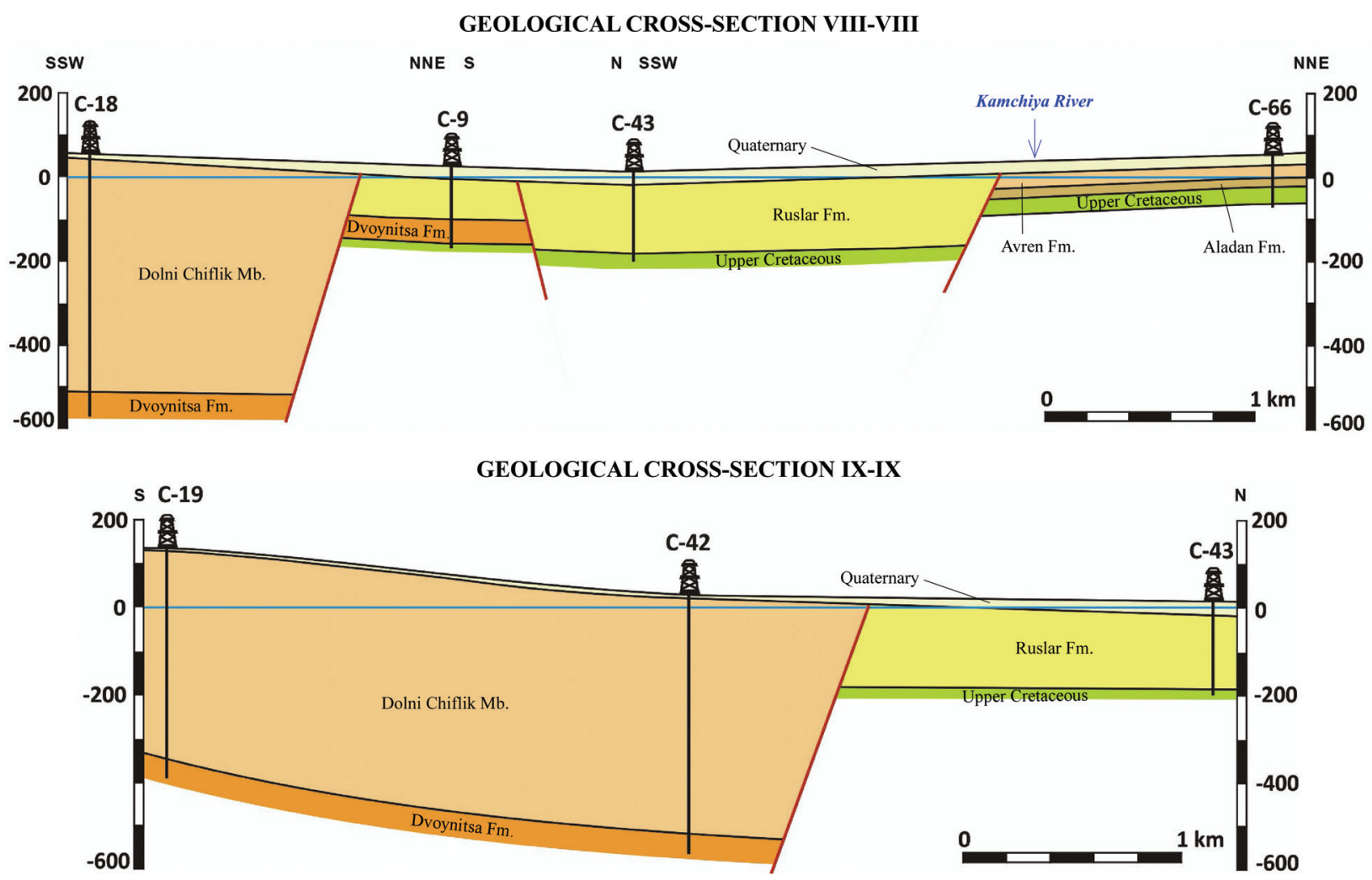

GEOLOGICAL CROSS-SECTION X-X
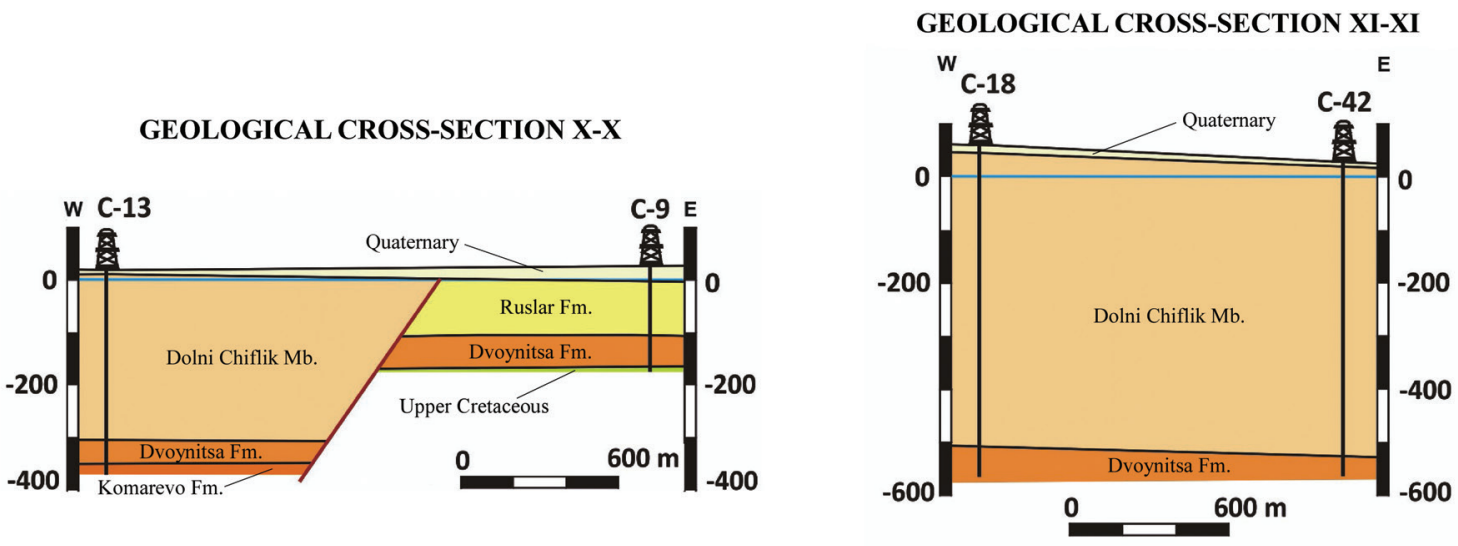

Fig. 8. Geological cross-sections VIII-VIII, IX-IX, X-X, and XI-XI

Фиг. 8. Геоложки разрези по линиите VIII-VIII, IX-IX, X-X и XI-XI

Dolna Kamchiya Basin (Valchev et al., 2018, 2020) and the Eastern Balkanides (Vangelov, Sinnyovsky, 2011).

The Dolni Chiflik Member's features (lithology, thickness, boundaries, and age) are the same as in the Dolna Kamchiya Basin.

The Ruslar Formation demonstrates comparatively homogenous structure. Similar characteristics were observed in the Avren Step (Valchev, Dimitrov, 2020). The thickness of the unit in the Goren Chiflik Horst is the smallest amongst the studied areas in Northeast Bulgaria.

\section{Discussion}

The geological cross-sections, drawn up after the lithostratigraphic interpretation of the borehole's lithological logs (Figs 5-8), and the two interpreted here seismic profiles (Fig. 9) revealed that the internal structure of the Goren Chiflik Horst is complicated. A series of normal faults, predominantly with $\mathrm{N}-\mathrm{S}$ and $\mathrm{W}-\mathrm{E}$ direction, have displaced the pre-Paleogene basement and partly the Paleogene succession, and have formed blocks with varied sizes and elevation. As a result, the Paleogene record demon- 

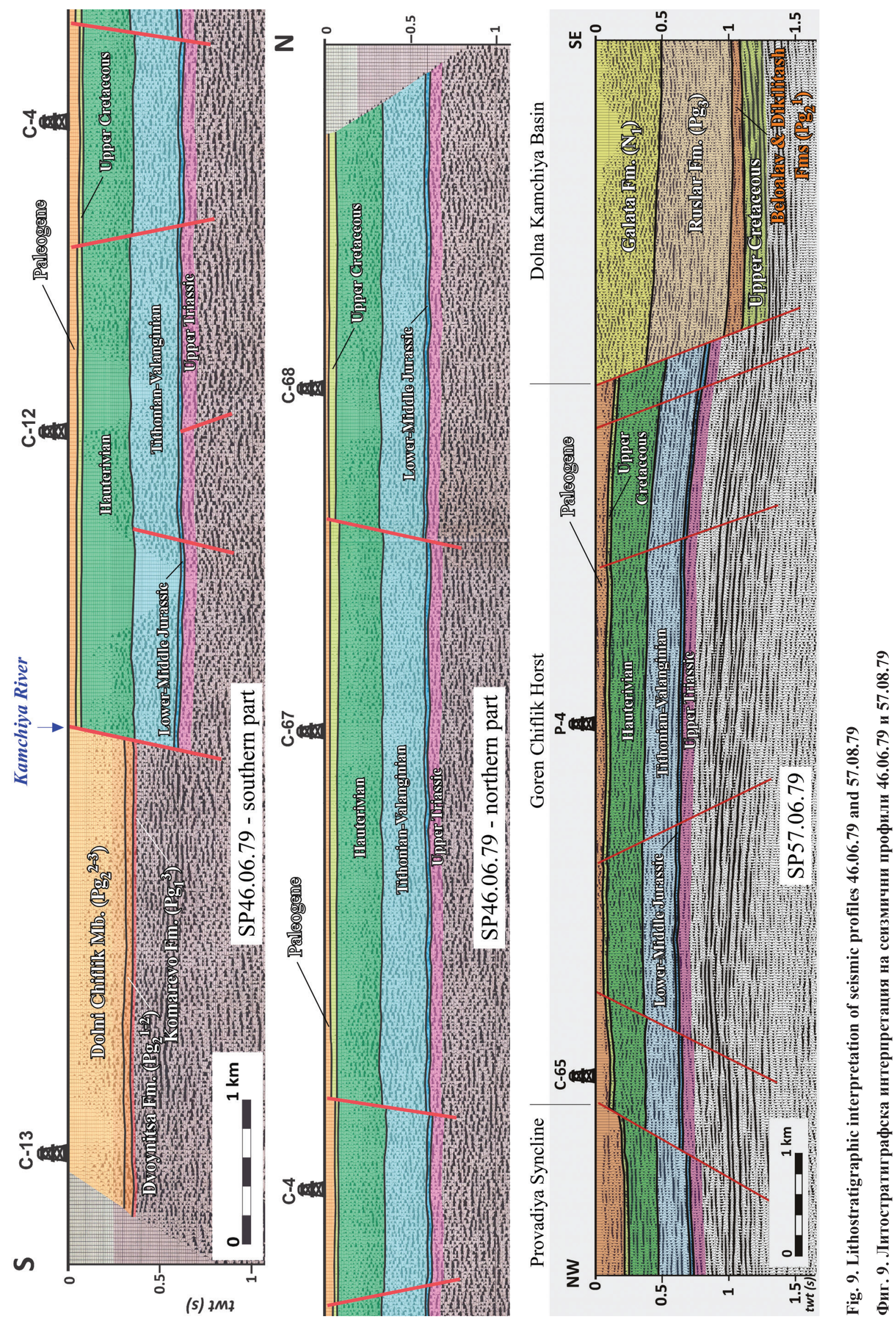
strates variations concerning the lithostratigraphic composition and the thickness. On the other hand, the lack of lithostratigraphic units in some areas is possibly due to the erosion at the end of the Lutetian of sedimentary successions deposited during the Thanetian-Lutetian interval on the most elevated blocks. The available data (the borehole network is clustered mainly in two areas - Fig. 3) do not allowed us to characterize the lateral relationships between the northern and southern lithostratigraphic successions.

\section{Conclusions}

The lithostratigraphic investigation of the $\mathrm{Pa}$ leogene in the Goren Chiflik Horst by means of lithostratigraphic interpretation of borehole logs confirmed the wide subsurface distribution of the Paleogene sedimentary successions across the entire investigated area. The presence of eight formal lithostratigraphic units, which have been previously described, was proven. New data, concerning the lithology, thickness, boundaries and spatial relationships, were added to their characteristics. The data, obtained from the geological cross-sections and seismic profiles, revealed a dynamic depositional environment during the Paleogene. Two lithostratigraphic successions were established in the northern and southern part of the Goren Chiflik Horst, respectively.

The collected database gives a good opportunity for clarifying the Paleogene part of the deep geologic structure of this sector of the Moesian Platform, and also for further palaeogeographic studies.

Asknowledgements: The authors thank Dr. Sava Juranov, Depatrment of Geology, Palaeontology and Fossil Fuels, Sofia University "St. Kliment Ohridski" for the kindly provided foraminiferal data as well as for his useful suggestions.

\section{References}

Aladjova-Khrischeva, K. 1984. Stratigraphie des dépôts éocènes aux environs du village Beloslav, département de Varna. - Rev. Bulg. Geol. Soc., 45, 1, 33-44 (in Bulgarian with French abstract).

Aladžova-Hrisčeva, K. 1990. Stratigraphy of the Lower Eocene sediments in part of the plateaus in Northeast Bulgaria. Rev. Bulg. Geol. Soc., 51, 1, 21-31 (in Bulgarian with English abstract).

Aladjova-Chrisčeva, K. 1991. Stratigraphic subdivision and correlation of Paleogenic deposits in Northeast Bulgaria. - Geologica Balc., 21, 2, 12-38 (in Russian with English abstract).

Aladjova-Khrischeva, K., N. G. Muzilev, S. Juranov. 1983. New data on the Paleogene stratigraphy of Northeast Bulgaria. - C. R. Acad. Bulg. Sci., 36, 7, 937-940 (in Russian).

Atanassoff, A. 1961. Géologie du secteur maritime des Prébalkans et de la vallée de la Kamčia. - Trav. Géol. de Bulgarie, Sér. stratigr. et tectonique, 2, 99-157 (in Bulgarian with French abstract).

Belmoustakov, E. 1960. Sédiments Paléocènes dans le plateau de Momino, région de Varna. - Rev. Bulg. Geol. Soc., 21, 1, 106-109 (in Bulgarian with French abstract).

Belmoustakov, E. 1962. Stratigraphie du Paléogène Inférieur des plateaux de la Bulgarie Septentrionale. - Bull. Geol. Inst., 10, 89-118 (in Bulgarian with French abstract).

Belmoustakov, E. 1968. Paleogene. - In: Tzankov, V., Ch. Spassov (Eds). Stratigraphy of Bulgaria. Sofia, Nauka i Izkustvo, 309-340 (in Bulgarian).

Bokov, P., G. Georgiev, I. Monahov, A. Atanasov, S. Jelev, Ch. Dachev, D. Yordanova, M. Vavilova, M. Nikolova, R. Ognyanov. 1987. Tectonic zoning. - In: Bokov, P., Ch. Chemberski (Eds), Geological Premise for the Oil-gas Bearing of the Northeast Bulgaria. Sofia, Tehnika, 109119 (in Bulgarian).
Cheshitev, G., V. Milanova, N. Popov, E. Kojumdgieva. 1991. Geological Map of Bulgaria on Scale 1:100 000. Varna and Resort Zlatni Pjassaci Map Sheets. Sofia, Committee of Geology and Mineral Resourses, Department of Geophysical Prospecting and Geological Mapping.

Cohen, E. 1938. Geologische Profilen durch den Ostlichen Balkan mit besorderer Berücksichtigung auf die Erdölfrage. - Rev. Bulg. Geol. Soc., 10, 1, 1-34 (in Bulgarian with German abstract).

Dabovski, H., I. Zagorchev. 2009. Alpine tectonic subdivision of Bulgaria. - In: Zagorchev, I., H. Dabovski, T. Nikolov (Eds). Geology of Bulgaria. Part II, Mesozoic Geology. "Prof. Marin Drinov" Publishing House, Sofia, 30-37 (in Bulgarian with English abstract).

Datchev, D. 1975. Stratigraphie des dépôts Paléocènes dans la région de Pleven. - Rev. Bulg. Geol. Soc., 36, 1, 37-48 (in Bulgarian with French abstract).

Dzuranov, S., S. Darakchieva. 1986. Early-middle Eocene planktonic foraminifera from Dobrudža (Northeast Bulgaria). - Palaeontol., Stratigr., Lithol., 23, 3-24 (in Bulgarian with English abstract).

Georgiev, G. V., P. D. Mandev, S. P. Valčeva, T. K. Mincheva, S. K. Jelev. 1988. Oil-gas potential of the Mesozoic sediments in the Provadia syncline and Gornichiflik horst. Ann. Univ. de Sofia, Fac. géol. et géogr., 78, 1-géol., 150170 (in Bulgarian with English abstract).

Gočev, P. 1926. Über das Eocän in Nord-Ost-Bulgarien (Vorläufige Mitteilung). - Arbeiten Bulg. Naturforsch. Ges., 12, 87-90 (in Bulgarian with German abstract).

Gočev, P. 1929. Neue Beiträge zur Kenntnis des Alttertiäre in Bulgarien. - Zbl. Mineral., Geol. und Paläontol., Abt. B., $11,543-548$.

Gočev, P. 1933. Paläontologische und stratigraphische Untersuchungen über das Eocän von Varna. - Rev. Bulg. Geol. Soc., 5, 1, 1-82 (in Bulgarian with German abstract). 
Gočev, P. 1934. Geologische Notizen über die Umgebung der Seen von Varna. - Rev. Bulg. Geol. Soc., 6, 1, 31-60 (in Bulgarian with German abstract).

Juranov, S., H. Pimpirev. 1989. Lithostratigraphy of the Upper Cretaceous and Paleogene in the coastal part of East Stara Planina. - Rev. Bulg. Geol. Soc., 50, 2, 1-18 (in Bulgarian with English abstract).

Kânčev, I., Y. Gerčeva. 1992. Geological Map of Bulgaria on Scale 1:100 000. Dolni Čiflik Map Sheet. Sofia, Committee of Geology and Mineral Resourses, Geology and Geophysics Corp.

Kojumdgieva, E., T. Nikolov, I. Sapunov, Y. Tenchov, D. Tronkov, Kh. Khrischev, H. Chemberski, P. Tchoumatchenco. 1982. Stratigraphic Code of Bulgaria (lithostratigraphic units). - Rev. Bulg. Geol. Soc., 48, 3, 286-310 (in Bulgarian with English abstract).

Mandev, P. 1955. Über das Paläogen im Stalin-Gebiet. - Ann. Univ. de Sofia, Fac. biol., géol. et géogr., 49, 2-géol., 73154 (in Bulgarian with German abstract).

Pollak, A. 1933. Geologische Untersuchungen über das Endstuck Ostbalkans. - Abh. Math.-Phys. Kl., Sächsischen Akad. Wiss., 41, 7, 1-60.

Stoykova, K., D. Vangelov. 1997. Nannofossil stratigraphy of the Lower Paleogene in Varna area (North-East Bulgaria). - Rev. Bulg. Geol. Soc., 58, 3, 179-187 (in Bulgarian with English abstract).

Tzankov, V. 1936. La stratigraphie de l'Éocène au Nord de la valée de Kamčia, Bulgarie du Nord-Est. - Geologica Balc., 2, 1, 49-67 (in Bulgarian with French abstract).

Tzankov, V., R. Beregov. 1940. Géologie du plateau de Varna. - Rev. Bulg. Geol. Soc., 12, 2, 119-148 (in Bulgarian with French abstract).

Valchev, B., H. Dimitrov. 2018. Lithostratigraphic interpretation of seismic profiles on the example of the Paleogene in the onshore part of the Dolna Kamchiya basin (Eastern Bulgaria). - Rev. Bulg. Geol. Soc., 79, 3, 105-106.

Valchev, B., H. Dimitrov. 2019. A new view to the spatial distribution of the Paleogene lithostratigraphic units in the offshore part of the Dolna Kamchiya basin based on seismic profile's interpretation. - Rev. Bulg. Geol. Soc., 80, 2, 61-69.
Valchev, B., H. Dimitrov. 2020. New data on the Paleogene lithostratigraphic units' distribution in the Avren Step south of Varna and Beloslav Lakes based on borehole data and seismic profiles' interpretation.-Rev. Bulg. Geol. Soc., 81, $1,55-67$.

Valchev, B., D. Sachkov, S. Juranov. 2017. Onshore-offshore lithostratigraphic correlation of the Paleogene in Northeastern Bulgaria based on 3D modeling. - In: National Scientific Conference "Geosciences '2017", Short Comm. Sofia, Bulg. Geol. Soc., 101-102.

Valchev, B., D. Sachkov, S. Juranov. 2018a. 3D lithostratigraphic model of the Paleogene of the onshore part of the Moesian Platform (Northeast Bulgaria). - Geologica Balc., 47, 1, 23-36.

Valchev, B., H. Dimitrov, D. Sachkov, S. Juranov. 2018b. New data about the Dvoynitsa Formation distribution in the onshore part of the Dolna Kamchiya basin (Eastern Bulgaria) on the base of 3D lithological modeling. - C. R. Acad. Bulg. Sci., 71, 12, 1252-1256.

Valchev, B., D. Sachkov, S. Juranov. 2019. Paleogene lithostratigraphy in the Varna Plateau (Northeastern Bulgaria): a new view based on 3D modeling. - Rev. Bulg. Geol. Soc., $80,1,41-53$.

Valchev, B., H. Dimitrov, D. Sachkov, S. Juranov. 2020. A new concept for the Paleogene lithostratigraphy in the onshore part of the Dolna Kamchiya Basin (eastern Bulgaria) on the basis of 3D modeling. - Geologica Balc., $49,2,59-73$.

Vangelov, D., D. Sinnyovsky. 2011. New data about the Dvoynitsa Formation distribution, lithology and chronostratigraphic range, East Bulgaria. - Ann. Univ. de Sofia, Fac. géol. et géogr., 49, 1-géol., 43-70 (in Bulgarian, with English abstract).

Yolkichev, N. 1986. Lithostratigraphic units related to the Upper Cretaceous in the west and central Fore-Balkan. - Rev. Bulg. Geol. Soc., 47, 3, 49-61 (in Bulgarian with English abstract).

Zlatarski, G. 1927. La Géologie de la Bulgarie. Sofia, Publ. House "Hudozhnik", Univ. Library, 65, 268 p. (in Bulgarian with French abstract). 